\title{
WOMEN'S ACCESS TO ISLAMIC HIGHER EDUCATION
}

\author{
Dyah Nawangsari \\ IAIN Jember \\ Jl. Mataram No. 1, Mangli, Kaliwates, Jember, Jawa Timur, Indonesia, 68136 \\ Email: dyahnawangsari@iain-jember.ac.id
}

\section{Aminullah Elhady}

IAIN Jember

Jl. Mataram No. 1, Mangli, Kaliwates, Jember, Jawa Timur, Indonesia, 68136

Email: aminelhady@iain-jember.ac.id

\section{Norodin Salam}

Islamic Studies, Cotabato City State Polytechnic College

Sinsuat Ave, Cotabato City 9600 Maguindanao, Philippines

Email: norissalam@yahoo.com.ph

Received: 09, 2020. Accepted: 12, 2020. Published: 12, 2020

\begin{abstract}
This study aims to describe women's access to PTKI (Perguruan Tinggi Keagamaan Islam/Islamic Higher Education) and ma'bad aly institutions. The method used was a qualitative approach with a gender perspective. Interviews, observations, and documentary studies were applied to collect the data. This research was conducted in PTKI and ma'bad aly institution that are located in East Java. The results show that there are gaps in accessing education between male and female students in the national context which can be seen from the net enrollment rate. This gap also occurred in women's educational participation at PTKI and ma'bad aly institutions. The disparity of education access can be observed in terms of women's participation in intracurricular and extracurricular activities at ma'had aly institutions. There is a difference in the level of women's participation in Islamic higher education for Islamic studies compared to ma'had aly.
\end{abstract}

Keywords: Educational Access, Intracurricular, Extracurricular, Ma'bad Aly

\begin{abstract}
ABSTRAK
Penelitian ini bertujuan untuk mendeskripsikan akses perempuan terbadap pendidikan di PTKI dan ma'had aly. Metode yang digunakan adalab pendekatan kualitatif dengan perspektif gender. Wawancara, observasi, dan studi dokumenter diterapkan untuk mengumpulkan data. Penelitian ini dilaksanakan di PTKI dan ma'had aly Jawa Timur. Hasil penelitian menunjukkan bahwa terdapat kesenjangan untuk mengakses pendidikan anak laki-laki dan perempuan dalam konteks nasional yang dapat dilibat dari Angka Partisipasi Murni. Kesenjangan ini juga terjadi pada partisipasi pendidikan perempuan di PTKI dan ma'had aly, terutama dalam kegiatan intrakurikuler dan ekstrakurikuler. Terdapat perbedaan tingkat partisipasi perempuan dalam pendidikan tinggi Islam dan pendidikan tinggi untuk studi Islam dibandingkan ma'bad aly.
\end{abstract}

Kata Kunci: Akses Pendidikan, Intrakurikuler, Ekstrakurikuler, Ma'had Aly 


\section{INTRODUCTION}

People's basic needs have changed from time to time. In the past, people's basic needs were limited to three main areas: clothes, food, and shelter. Along with life development, these basic needs also change to more than just those three areas. For instance, education offers new basic needs, besides entertainment and communication. It can be said that all society levels have made education something that must be fulfilled, both urban and rural community, men and women. Women have considered that education can empower their life both in their career in their choice of profession for those from middle income countries (Samarakoon \& Parinduri, 2015)

The different opportunity to access for men and women to get an education has been a phenomenon for a long time, in many parts of the world, especially in developing countries. For example, in the Middle East, as in other Eastern countries, girls do not have equal and similar opportunity as their counterpart have to get an education in schools. Since girls and boys are human beings who have physical, psychological, and intellectual abilities, they should be given similar and equal opportunities by the society and school in particular to be trained and developed to achieve their fullest development (Amin, 2016).

An international organization focusing on education, science and cultural organization, UNESCO (2014) reported that two-third of 774 million illiterate adults around the world were women. Among the illiterate youth number of 123 million, 76 million were female. It was in line with the report released by UN Women, (2012). Its website released a report noting that twothirds of the 796 million illiterate people are women. The institution points to an imbalance between girls and boys. In global statistics, it is stated that just 39\% of rural girls attend secondary school, while rural boys $45 \%$, urban girls $59 \%$, and urban boys $60 \%$. While progress has been made in reducing the gender gap in urban primary school enrolment, data from 42 countries shows that rural girls are twice as likely as urban girls to be out of school. This inequality also occurs in Saudi Arabia where women experience inequality for access to education (Hamdan, 2005).

During the Dutch colonial government in Indonesia, women generally experienced this inequality. In some cases, this gap did not happen for women from the haves financially or aristocracy in terms of social level who received special treatments from the colonial and the society. In general, the governing authorities at that time encouraged the parents to focus their daughters to prepare to become wives and mothers when they got married. Women from the lower classes were considered not to need access to education. The idea of equality of men and women was not supported by the society (Mufidah, 2017) The old mindset is still deeply embedded among the people. In the New Order era, girls were advised and prepared to get married and serve as a wife and to support motherhood in a family. In particular, women are expected to provide support in nation-building, becoming the mothers of the nation. Additionally, women also have more responsibilty for education for the family, community, and nation (Djajadiningrat, 1992).

Even though female join schools, they still to some extent experience gap either in education disparity or intra and extracurricular activity. The phenomenon appears in their participation in school activities. In school activities, males are always more active than females. Likewise, in extra-school organizations, girls are almost always in a position to have less and fewer chance to exhibit their actual competence and performance in leadership and organization. They were related to their image that is weak and subordinate as a female. This fact also shows that there are still obstacles for girls to have equal and similar access to participate in school activities. In the society and school, females are placed in the position that makes it difficult for them to enjoy equal opportunity to access in education. This can also happen in Islamic education institution (Srimulyani, 2007). 
In Indonesia, the government provides regulations for Islamic higher education types. One of them is PTKI (Perguruan Tinggi Keagamaan Indonesia/ Indonesian Islamic Higher Education). which specialized Islamic and other discipline. The other refers to Islamic higher education called ma'bad aly, which has been different from PTKI in academic cultures and regulations.

Indonesian higher education is organized by Law 12 of 2012 on Higher Education and Governmental Regulation No. 4 of 2014 on the Operating Higher Education and Higher Education Management, and Education Ministerial Regulation No. 3 of 2020 on National Standard of Higher Education. Meanwhile, the legal basis for ma'bad aly is Governmental Regulation No. 46 of 2019 on Religious Higher Education. According to Religious Ministerial Regulation No. 71 of 2015, article 1, point 1, ma had aly is an Islamic religious college that organizes academic education in Islamic religion mastery (tafaqquh fi al-din) based on the classical Islamic books organized by pesantren. Ma had Aly organizes academic education at the Undergraduate and Postgraduate levels (Yasid, 2010). The held education is specialized and deepening (takhassus) in specific fields of Islamic studies.

In this study, there are some PTKI institutions that were used as a locus of study. For the PTKI category, the study was conducted in three institutions; they are Yudharta University of Pasuruan as the Islamic higher education, State Institute for Islamic Studies (IAIN) Jember, and Islamic Institute of Al-Falah Assunniyah (INAIFAS) Jember as the higher education for Islamic Studies. On the other hand, ma'had aly category has been applied and carried out in three institutions such as Ma'had Aly of Salafiyah Syafi'iyah at Sukorejo Situbondo, founded in 1990 (majoring in Figh and Usül Fiqh studies), Ma'had Aly of Nurul Jadid at Probolinggo, founded in 2018 (majoring in Fiqh, Mu'ämalah, and Tlm Falaq studies), and Ma'had Aly of Hasyim Al-Asy'ari at Tebuireng Jombang, founded in 2016 (majoring in Hadith and Hadith Sciences).The selection of higher education was based on the consideration of the participation of women graduated from high school to continue to higher education. In this study, higher education institutions are under the control of the Ministry of Education and the Ministry of Religious Affairs.

The issue of woman and education have attracted both national and international scholars especially when it comes to education disparity. It includes the issue of woman and education in Saudi Arabia in terms of the challenges and its achievement (Hamdan, 2005); the issue of women's experience of higher education in Britain (Ahmad, 2007). In Indonesian context, studies related to the issue of women and education have been conducted by researchers. The studies covered topic related to whether education empower Indonesian women (Rohman, 2013); topic on Indonesian Muslim women and their gender equality movement in Indonesia (Qibtiyah, 2009). Other studies deal specifically with efforts and strategies to deal with gender gap. A study investigated how difficult it is to deal with the complexities issue in dealing with gender inequality for women to access education (Mufidah, 2017). Other study examined an issue on women and their leadership roles in Islamic higher education since they occupy strategic position to carry out and make decision in a particular organization (Muluk, 2014).

Some studies have specifically address muslim women and their inequality in Islamic education. A study has been conducted to investigate muslim women and the issue of inequality that they experience at pesantren. The Islamic education institution are likely to put girls in a position that make them difficult to gain and strive educational activities (Srimulyani, 2007). Another study has explored in general whether education has empowered women ( Samarakoon $\&$ Parinduri, 2015). Since education is pivotal to empower women, it should be designed to be open and accessible by women. However previous studies have not explored muslim women and their experience to study in Islamic higher education and ma'had aly. Many types of research are concerned about women's experiences, especially in their education life. However, the research that only focuses on the Islamic education field, especially with specific field categories, remained rare. 
This study aims to fill the gap. It investigated women's participation in accessing Isalmic higher education institution both PTKI and ma'bad aly. For this purpose, it includes the sustainability of women's education and the reasons for being out of the study. In addition, it also discusses the obstacles they faced in intra and extra-school activities, their experiences during their education, and the historical background that caused that experience to occur. Therefore, this research focuses more on higher education in Islamic institutions, where there were differences in access opportunities between men and women. One of the reasons is the tendency to understand the sacred text, as understood by generations of past scholars.

\section{METHOD}

This study applied phenomenological type of qualitative approach to collect the data. It was used to analyze the issue investigated in this study that is women's access in higher education (Reinharz, 2005). Since the subjects studied in this study were about women, this study analysed the issue using a gender perspective (Abdullah, 2001). In this case, the study applied Moser's model (1993) to capture gaps in the access, participation, control, and benefits for females in accessing higher education. The researchers played crucial role as an instrument in this study. The researchers conducted interviews, observations, which were equipped with documentary studies and literature reviews. Among the informants in the study were college leaders, student, kyai, and nyai as caretaker of the Islamic Boarding School While to avoid bias and ensure data validity, triangulation techniques were used.

\section{RESULTS AND DISSCUSSION}

This study has several findings. It started with women's participation and gaps in education in the national context. Next, it features women's participation in Islamic higher education institutions either in PTKI or ma'had aly. Then, it describes women's access to school activities both intra and extra-curricular activities. Finally, it describes educational sustainability of women in Islamic higher education institution. After the findings are delivered, discussion is provided at each section to position the findings of the study in relation to its contribution to the body of the knowledge.

\section{Women's Participation and Gaps in Education}

Various development efforts were made to provide the most expansive space for women's education participation. These efforts show the results namely the tendency to increase the NER (net enrollment rate) of girls in participating in any level of education from year to year. According to the studies conducted on community participation in education at the primary, secondary, and higher education levels, there are differences between boys and girls for their education participation.

The increase of NER for education shows that there has been a change in people's mindset. This is marked by providing a space where women's participation in education is strongly encouraged. They are expected to enjoy other roles in education in addition to social role as mother in a family institution. However, this increase has not eliminated the gap in education levels between male and female students.

Referring to the National Socio-Economic Survey on the population, this study found the percentage of 15 years and over in the category of sex. They were still in school from 2011 to 2015. It shows that female have a lower level of education compared to male. In other words, the higher, it is common to see that female students are absent when it comes to higher education. This survey also proves that the higher the level of education, the more visible the gap between male and female students. This is to say that women have fewer chance and access to pursue their dream to achieve higher education or at university level. It can be shown in the following table. 
Table 1. Populations of 15 Years Old and Over who were Enrolled in chool

\begin{tabular}{cccc}
\hline No. & Year & Male $(\%)$ & Famale $(\%)$ \\
\hline 1. & 2011 & 24.69 & 23.85 \\
\hline 2. & 2012 & 25.12 & 24.41 \\
\hline 3. & 2013 & 25.72 & 24.93 \\
\hline 4. & 2014 & 26.81 & 25.86 \\
\hline 5. & 2015 & 26.10 & 25.56 \\
\hline
\end{tabular}

Source: (Susenas, 2011-2015)

Although the NER of women in education tended to increase, it has not eliminated the gap in education levels between male and female students. The National Socio-Economic Survey results showed that the percentage of males and females who have primary education diploma was relatively equal. Meanwhile, the percentage of females aged 15 years and over who did not have a diploma was $21.51 \%$, which was far higher than that of males, only amounted to $15.51 \%$. The educational gap might be seen in the percentage of females aged 15 years and over who had a high school diploma, namely $21.77 \%$, much lower than that of males at $26.85 \%$. While in higher education, it was $7.98 \%$ for males and $7.92 \%$ for females. It shows a gap between male and female in education. It can be seen in the following table.

Table 2. Populations of 15 Years Old and over who Completed Education

\begin{tabular}{clcc}
\hline No. & Education Level & Male $(\%)$ & Female $(\%)$ \\
\hline 1. & Noncertified & 15.51 & 21.51 \\
\hline 2. & Primary school & 27.71 & 27.87 \\
\hline 3. & Secondary school & 21.95 & 20.93 \\
\hline 4. & Diploma & 26.85 & 21.77 \\
\hline 5. & Higher education & 7.98 & 7.92 \\
\hline
\end{tabular}

Source: (KPPA, 2016)

The gap between males and females pursuing education at a higher-level show that there are still obstacles for women to have equal access in pursuing education. Although the NER of women at various levels of education has increased every year, it does not mean that the access constraints have disappeared because the NER does not describe the sustainability of women's education. This factor should be taken into consideration if the government and the society are in a position to deal with the education disparity. In fact, the demands of social values in society which is patriarchal in nature provide more subordination to education for women (Knop, 2007; Saputro, 2010).

In education, girls and boys should be considered equal as human beings who have physical, psychological, and intellectual abilities. Those abilities should be developed regardless of their sex. They should be given similar and equal opportunities by the society and school in particular to be trained and developed to achieve their fullest development (Amin, 2016). When women have equal opportunity in education, they can pursue to have a better choice for their life. Education can empower their life both in their career in their choice of profession for those women from middle income countries (Samarakoon \& Parinduri, 2015).

Gap in education for females does not only happen in Indonesia. In other parts of the world, this issue occurs and seems common in developing countries. This education inequality also occurs in middle east country like Saudi Arabia where women experience inequality for access to education. They experience several types education gap in the society (Hamdan, 2005). In any country or culture where the culture is dominated by the male, women are likely to suffer from education gap. This has something to do with the idea of equality of men and women which was not supported by the society (Mufidah, 2017). In the society and school, females are placed in the position that makes it difficult for them to enjoy equal opportunity to access in 
education. This can also happen in any education institution like in pesantren or other Islamic education institutions (Srimulyani, 2007).

\section{Women's Participation in Islamic Higher Education Institutions}

The participation rate of women in several higher education is related to the competency of graduates. It can be seen in PTKI institution category. For example, at IAIN Jember and INAIFAS, although women's participation is higher than that of men in general, several study programs show the opposite, namely the study programs of hadith science, family laws, and constitutional laws. The study programs aim to prepare experts of hadith, Islamic law, and judges that are almost identified to males. On the other hand, the study program that aims to prepare graduates in teacher training, counseling, and banking is always interesting for female students. These professions are identified to women.

The choice regarding study program in higher education institutions is still influenced by the view of differences between men and women. The worldview assumes that men are superior and women are inferior. Men are rational and women are emotional. strength of men, and weakness of women is also preserved in this worldview. Although those traditional views have been questionable and debatable among the students, they cannot be completely rejected. In fact, these values affect professional education, limit women's involvement in the labor market, conditions, and types available for them (Mosse, 1993). Although women's participation in education is relatively high, women still have obstacles to access education with specific skills. This is very evident in the participation of women at the Yudharta University of Pasuruan. The faculty of engineering, food technology, and industry are dominated by male students, while females dominate the faculty of administration sciences and the faculty of teacher training. Thus, gender roles and functions still motivate women's participation rates in higher education.

From the research conducted in higher education, it was found that women's participation in continuing their study increased, even higher than that of men, both in the general Islamic higher education and in ma'bad aly. This proves that women's access to higher education institutions became wide open. The opened access to education for women has also occurred in several countries where most of the population are Muslims.

In countries with a majority Muslim population, women are almost always positioned as "second class citizens". This is to say that females' rights for education are often neglected (Supriadi et al., 2019). They have smaller chance to access education compared with their counterparts. In the Western culture, Muslim women are considered the others. In this context, Muslim women are oppressed by social values. The society should pay more attention to provide females equal opportunity to education. This effort can help women access education with similar opportunity to men (Abu-Lughod, 2002).

In line with this gap opportunity in education, there is the case of Bangsamoro women in Southern Philippines. The women are being neglected in terms of their education rights. They have been affected by the strong influence of historical injustice. This social injustice has been a burden for women in getting a quality education or continuing their studies. Their unfortunate condition makes them difficult to participate in the professional working force (Buenaobra, 2011). Their educational gap makes their life unfortunate to access more income for their life.

This assumption encourages scientists to conduct research related to Muslim women's access to education. Among these were conducted by (Sahu et al., 2019), who discovered that Muslim and Hindu women in Bengaluru, South India, faced different barriers in accessing education. These barriers include finance, security in public areas, gender bias, social issues, and community domination. For Muslim women, these obstacles are exacerbated by their status as a minority. Being minority in the society has made the situation worse to access education. It shows complex intersectional barriers (financial, social, and structural) for women in accessing 
higher education. It goes without saying that women face multidimensional burden to enjoy equal opportunity for education.

In New York, education gap also happens. Silverman (2012) investigated Muslim minority communities of Romanian Muslim women in New York. The study showed that the participation rate in Romanian women's education is higher than that of men. However, this does not mean that the education of Romanian Muslim women is without obstacles. The main obstacles are in terms of mobility and sexuality of the women. As a community of migrants, they must maintain and preserve the values and traditions instilled by their ancestors. This demand has something to do with females' role in the society. The society requires female to deliver baby or the next generation in the society. That is why parents forbid their daughters to associate with non-Romanian citizens. It has an impact for women in terms of educational opportunity. They have less and fewer chance to access education.

Barriers to women in accessing higher education also occur in almost all Muslim countries. Bearing in mind that only in the 19th century, several figures appeared to call for the opening of education for women. Al-Tahtawi from Egypt (1801-1873) has been the first person to campaign for gender equality and justice. He also called for the opening of equal education access for women. This marked the historical movement for women to gain more opportunities and equal access to education.

In Indonesia, girls got an equal position in pesantren education since the early 20th century (Dhofier, 1982). Women's access to formal education has been declared since the Joint Ministerial Decree (SKB) number 6 of 1975 is published. The decree recognized that madrasah is equal to school so that madrasab graduates could continue their study to religious higher education and as well as the public one. This gave Muslims benefits especially for women. Historically, women' educational participation in Indonesia has been limited to diniyah or madrasah education only. Their status had not been recognized as formal education prior to the release of the decree. With this policy, many women could access general higher education to improve their living standards and pursue more opportunity to participate in working labor. The opened access to education for women has made their participation rate in religious higher education improved. Studies in higher education in East Java have proven that this trend has existed in the last few years.

Iran has also witnessed the emergence of education equality for girls. Shams (2016) found that since the Iranian revolution in 1979, women have gradually dared to question and even protest patriarchal views wrapped in religion. This effort has yielded results in the form of increasing women's access to public spaces, including opportunities in employment and education. In fact, since 2016 Iranian Muslim women's participation in higher education institutions has reached 60\%. The study held by (Jamjoom \& Kelly, 2013) about Higher education for women in Saud Arabia found that since 1975, women's participation increased to 14\% of all Saudi Arabia students. The rapid increase occurred between 1990 and 2004 at 51.2\%. Next, in 2013 female students made up 60\% of all students in the country.

\section{Women's Access to Intra and Extra-Curricular Activities}

The different academic climate in the general higher educations and ma had aly institutions also has implications for women's access to intra and extra-campus activities. In general higher educations, women have more open access than ma'bad aly. This open-access allows women to participate freely in every campus activity without experiencing significant obstacles.

At the campus of Yudharta University, female students are given the same space as male, even though this campus is located within the pesantren of Ngalah Pasuruan. Thus, there are no obstacles at all for women to participate in intra and extra-campus activities. Learning on this campus is carried out simultaneously between male and female students. (Anan, personal communication, June 11, 2020). The educational access for female students was also found at 
INAIFAS. Since its establishment in 1999, it did not impose segregation in every aspect of its education. However, since 2016 there has been a separate classroom for males and females, considering the increasing student number (Nafiurrafid, personal communication, July 6, 2020; Syaekhu, personal communication, July 6, 2020).

In the general higher education environment, a conducive climate must be created to develop fresh ideas regarding the practice and actualization of Islamic teachings. One of the fresh ideas being developed at this time is the idea of gender equality. Gender equality is not considered as a campus discourse but it has become part of the national development issues. The government has issued Presidential Instruction No. 9 of 2000 on Gender Mainstreaming in National Development. This program is deliberately created to integrate gender issues as an integral part of planning, formulating, implementing, monitoring, and evaluating national development policies and programs.

The regulation has been supported by the Religious Affairs Ministerial Regulation No 11 of 2006 on the Establishment of a Gender Mainstreaming Task and Function Implementing Unit within the Ministry of Religious Affairs. This ministerial regulation forms the basis for every agency under the ministry to implement it in their respective work programs (Direktorat Jenderal Pendidikan Islam, 2016).

Ma'bad aly of Salafiyah Syafi'iyah also maintains a strict separation between male and female students. The separation was carried out starting from the arrangement of the dormitory rooms, the administration office, the administration of education, to the student mobilization route. (Sari, personal communication, July 16, 2020; Djalal, personal communication, July 16, 2020).

This separate model often makes female students feel difficult because they are bound with stricter regulations than men. One of the regulation items, the access to the library for female students is not as free as male, because the library is located near the male dormitory. Also, access constraints exist when female students want to do comparative studies, conduct research, or explore knowledge outside the pesantren; they must get permission, which is difficult to obtain (Nabalah, personal communication, August 16, 2020; Eva, personal communication, August 16, 2020).

Extra-campus activities for female students are also carried out separately from male students. They have a special discussion group, the tanwir, to discuss social issues in Islamic law. The forum discussion results will later be published in a compilation book of Islamic law entitled Tanwirul Afkear. Although the forum was held for male and female student groups, the published material in Tanwirul Afkar were mostly of the male students. The absence of female writers in publication because of the lack of female writers among the students.

In contrast to female students' experiences in Ma'had Aly of Salafiyah Syaficiyah, in Ma'had Aly of Nurul Jadid, access for a female is relatively more open. Although ma'bad aly has separated educational patterns, the lecture hall is provided for all. The lecture hall is located in the female dormitory. The students of Ma'had Aly of Nurul Jadid come from various backgrounds of ability levels of kitäb reading. There are three classifications in the ma'bad aly class, namely the tambidi class (beginners) for those who can read the Qur'an and to write pego (Arabic-Malay or Jawi letters), the next is $i$ 'dädi level (preparation class, for those who can read the kitab kuning but not too proficient), and the third is the ma'bad aly level. These three levels of learning, the institution facilitates female's access to become students of tambidi $i^{i}$ dàdi, and ma'bad aly levels even though those who reached the level of ma'bad aly are not all total of the students. (Latifah, personal communication, August 6, 2020).

Access to campus facilities is also quite open for female students. They are free to access the library because the library is in a building that is separated by a curtain between male and female students. The library of ma'bad is also located in the female dormitory complex, but there 
is special access way for each male and female students to the library. The female students are also often involved in a discussion forum, namely bahth al-masäil, with male students. Even sometimes, there is a competition between the two groups (Rara, personal communication, August 6, 2020; Fatimah, personal communication, August 6, 2020).

The other obstacle they often face is the limited access to discuss with male lecturers due to the distance between the female dormitory and the male's boys' where the lecturers stay. While male students may freely deliver questions and discuss with the lecturer whenever they will. The next obstacle is in falaq practice session for ru'yat al-bilal (observing the month for determining the beginning of the Lunar months), which invites female students' difficulties, because they must be in a group with male students.

Educational access for female students at Ma'bad Aly of Hasyim Al Asy'ari differs from the two previous ma'bad aly. The institution of Ma'bad Aly of Hasyim Al Asy'ari - founded in 2006- initially accepted male students only, but since 2008 it has accepted female students and realized a mixed learning model between male and female. Since 2015, the separate learning has been carried out. However, under certain conditions and for some reasons, learning is realized mixed without any curtains. (Syakir, personal communication, August 16, 2020)

The lectures are held under the same building in the separated classrooms of male and female. On the same day, lecture hours are alternately arranged between males and females classes. They can meet and communicate freely because all facilities are shared. There is no prohibition on bringing communication tools for the students, so it makes them easier to access knowledge anytime and from any source. (Fauzi, personal communication, August 16; Rabiatul Adawiyah, personal communication, August 16, 2020)

The equal access opportunity between men and women is based on a balanced interpretation of the verses on the men's superiority on the one hand and the verses which contain the command to treat women well on the other side (Rosidah, 2012; Firdaus \& Arifin 2018). The tight restrictions of space for women are not realized because the faith basis and conscience are more effective than the physical aspects. Ma'bad Aly of Hasyim Al Asy'ari gives more open permission to the students to maintain morals and interactions with the opposite sex without too strict rules (Muhammad, 2014).

The issue of educational gap for women have attracted both national and international scholars. In Saudi Arabia, women experienced challenges to achieve educational opportunities. They should be supported by the society to achieve their educational opportunity (Hamdan, 2005). Likewise, in Britain, women experienced educational gap to access higher education (Ahmad, 2007). In Indonesian context, some studies related to the issue of women and education have been conducted by researchers. The findings of this study is in line with the previous study. Muslim women should be empowered to gain education opportunity to gain more independence for their life. Their independence can be achieved through equal opportunity in education (Rohman, 2013).

The findings of this study show that female have experienced inequlity to access intra and exrtra curricular activity in Islamic education institution ma'bad aly. This finding is supported by previous study. In Indonesia, the issue of educational disparity is difficult to deal with because of the complexities of gender inequality. Gender disparity should be taken into consideration by the society including pesantren if they are in a position to provide equal opportunity for girls in education (Mufidah, 2017). Pesantren should uphold and promote the equality of education both for boys and girls at pesantren. It takes time for pesantren to be able to support educational equality for girls and try to solve inequality of education for girls at pesantren. In the long run, girls may enjoy the equality of education at pesantren and can achieve their independence by being competent and knowledgeable in their competence (Srimulyani, 2007). 


\section{Educational Sustainability of Women in Higher Education Institutions}

There was a different trend in women's educational sustainability between the general higher educations and ma'bad aly. In the general higher educations, women had more possibilities to continue their education than those in ma'bad aly and a tendency that the number of female students was more than that of men. For example, in INAIFAS, the number of graduates in 2017/2018 were 110 female students and 104 male students. The similar also happened at Yudharta University, where the graduates in 2017/2018 were 199 females and 143 males. The fact was very different from what in the higher education category of ma'bad aly, which showed quite far difference in numbers. In Ma'had Aly of Salafiyah Syaficiyah Sukorejo, in the academic year 2016/2017, the students who completed their course were 96 males and only 54 females. This number was proportional to the number of participants of the final examination that year. The number of male students who took the final exam was 106 students, where $33(31 \%)$ of participants passed, and $10(9.4 \%)$ did not pass, while the remaining $63(59.6 \%)$ had to take a reexam. On the other hand, from 54 female students, nine of them have passed the exam $(16.7 \%)$, seven of them $(13 \%)$ did not pass, and the remaining of them $(70.3 \%)$ had to retake the exam.

The difference in graduation tendency in general higher educations and ma had aly was more influenced by the different academic climate between the two categories of institutions. The academic climate in general higher educations provided space for women more freely than in ma'had aly. Women got the same rights and treatment as men in higher education, so they might freely discuss and seek information from whomever and whenever they want. Such an academic situation provided opportunities for females to achieve the highest possible achievement and even surpassed males.

The academic climate of ma'bad aly was very different from others, especially in the pesantren environment. The students of Ma'had Aly were placed in separate classrooms. This separatation had implications for differences in treatment between male and female students. This condition made it difficult for women. Another difficulty faced by female students was the prohibition of marriage for students while studying at ma'bad and that was applied in Ma'had Aly of Hasyim al Asy'ari. The prohibition most of the reasons for dropping out of higher education. Although there was no specific prohibition to female students for married at Machad Aly of Salafiyah Syafi'iyah and Ma'had Aly of Nurul Jadid, this issue also became the main reason for female students stopping their study in ma'bad aly. The difference in academic climate and differences in treatment of female students between the general higher educations and ma'bad aly was due to the different interpretations of gender equality (Mashriqi, 2016).

Women should be supported to gain equal access to education. They will be empowered by education to strive for their life (Samarakoon \& Parinduri, 2015). The findings of this study to some extent is supported by previous study in the pesantren context where women have also gained equal opportunity to education (Srimulyani, 2007). Pesantren should be supported by the government and society to provide breakthrough in providing access to education for girls. The society especially girls in the face of disparity of education should struggle to achieve education equality. If the gap and disparity of education can't be resolved, there should be a movement to promote gender equality in education. The government and the society are expected to play the role to campaign for education equality (Qibtiyah, 2009).

\section{CONCLUSION}

This study investigated women's access to education in Islamic higher education and ma'bad aly. Based on the findings of this study, several points can be concluded. The participation of female is lower compared to male in education. This can be seen from national net enrollment rate for girls. Equality of access to education has not been achieved fully by women in Islamic higher 
education institutions either at PTKI institution or in ma'had aly. They suffer from the minimum participation figures, obstacles in study completion and limited access to participate in intra and extra-curricular activities. Both institutions have different tendencies in providing access to women's education. In PTKI, access for women is wide open because this institution provides the most expansive possible space for interpretation of gender equality. On the other hand, in ma'bad aly institutions, the interpretation of gender equality is constrained by the social, religious considerations which originate from the interpretation of the sacred texts. It must adjust to local propriety, which is considered the truth in the pesantren where the ma'bad aly is located.

\section{BIBLIOGRAPHY}

Abdullah, I. (2001). Penelitian Berwawasan Gender dalam Ilmu Sosial. Jurnal Humaniora, 15(2). http://dx.doi.org/10.22146/jh.794.

Abu-Lughod, L. (2002). Do Muslim Women Really Need Saving?. American Anthropologist 104(783), 90. http://dx.doi.org/10.1525/aa.2002.104.3.783.

Amin, Q. (2016). Tahrir Al-Mar'ah. Cairo: Hindana.

Buenaobra, M. I. (2011). Gender and Conflict in Mindanao. In The Asia Foundation. Retrieved from https://asiafoundation.org/2011/10/19/gender-and-conflict-in-mindanao/.

Dhofier, Z. (1982). Tradisi Pesantren Studi tentang Pandangan Hidup Kyai. Jakarta: LP3ES.

Direktorat Jenderal Pendidikan Islam. (2016). Modul Pelatihan Anggaran Responsif Gender (ARG) dan Perencanaan dan Penganggaran Responsif Gender (PPRG) Bidang Pendidikan Islam. Jakarta: Kementerian Agama RI.

Djajadiningrat, M. (1992). Ibuism and Priyayization: Path to Power?. In Locher-Scholten, E. \& A. Niehof. Indonesian Women in Focus. Leiden: KITVL Press.

Ahmad, F. (2007). Muslim Women's Experiences of Higher Education in Britain. The American Journal of Islamic Social Sciences 24 (3), 46-69. https:// doi.org/10.35632/ajiss.v24i3.424

Firdaus, D., \& Z. Arifin. (2018). Pendidikan Perempuan Perspektif Quraish Shihab dalam Tafsir Al-Misbah. Jurnal Pemikiran Keislaman. 29(31). http://dx.doi.org/ 10.33367/tribakti. v29i2.595.

Hamdan, A. (2005). Women and Education in Saudi Arabia: Challenges and Achievements. International Education Journal, 6(1), 42-64

Jamjoom, \& Kelly. (2013). Higher Education for Women in Saud Arabia, in Larry Smith Dan Abdurrahman Abouammoh (Editors), Higher Education in Saudi Arabia: Achievements, Challenges and Opportunities. New York: Springer.

Knop, V. K. (2007). The Female Jihad: Al-Qaeda's Women. Studies in Conflict \& Terrorism 30(5). http://dx.doi.org/10.1080/10576100701258585.

KPPA. (2016). Statistik Gender Tematik Potret Ketimpangan Gender dalam Ekonomi. Jakarta: Kementerian Pemberdayaan Perempuan dan Perlindungan Anak.

Mashriqi, K. (2016). Afghanistan Women Perceptions of Access ToHigher Education. Journal of Research Initiatives, 2(1). Retrieved from http://digitalcommons.uncfsu.edu /jri/vol2/iss1/2

Mosse, J. C. (1993). Half the World, Half a Chance, an Introduction to Gender Development. Oxford: Oxfam.

Mufidah, Ch. (2017). Complexities in Dealing with Gender Inequality Muslim Women and Mosque-Based Social Services in East Java Indonesia. Journal of Indonesian Islam, 11(02), ,459-488. http://doi.org/10.15642/JIIS.2017.11.2.459-488

Muluk, S. (2014). Women and Leadership in Islamic Higher Education in Indonesia. Englisia, 1 (2), 172-190. http://doi.org/10.22373/ej.v1i2.27 
Muhammad, H. (2014). Islam dan Pendidikan Perempuan. Jurnal Pendidikan Islam. 3(2). 231-244. http://dx.doi.org/10.14421/jpi.2014.32.231-244.

Qibtiyah, A. (2009). Indonesian Muslim Women and the Gender Equality Movement. Journal of Indonesian Islam 3(1), 168. doi: 10.15642/JIIS.2009.3.1.168-196

Reinharz, S. (2005). Metode-Metode Feminis dalam Penelitian Sosial. Jakarta: Women Research Institute.

Rohman, A. (2013). Does Education Empower Indonesian Women? Jurnal Ultima Humaniora, 1(2), 103-108.

Rosidah, N. (2012). Fundamentalisme Agama. Jurnal Walisongo, 20(1), 1-23. http://dx.doi.org/ 10.21580/ws.20.1.182.

Sahu, B., P. Jeffery, \& Nakkeeran, N. (2019). Barriers to Higher Education: Communalities and Contrasts in Experiences of Hindu and Muslim Young Women in Urban Bengaluru, Compare: Journal of Comparative and International Education 47(2). 177-191 http://dx.doi.org/10.1080/03057925.2016.1220825.

Samarakoon, S \& Parinduri, R. A. (2015). Does Education Empower Women?. World Development, (66), 428-442. https://doi.org/10.1016/j.worlddev.2014.09.002

Saputro, M. E. (2010). Probabilitas Teroris Perempuan di Indonesia. Jurnal Ilmu Sosial dan Ilmu Politik, 14 (2), 211-228. https://doi.org/10.22146/jsp.10937

Shams, A. (2016). Revolutionary Religiosity and Women's Access to Higher Education in the Islamic Republic of Iran. Journal of Middle East Women Studies, 12(1). http://dx.doi.org/10.1215/15525864-3422633.

Silverman, C. (2012). Education Agency and Power Among Macedonia Muslim Romani Women in New York City. Signs: Journal of Women in Culture and Society. 38(1). http://dx.doi.org/ 10.1086/665803.

Smith, L., \& Abouammoh, A. (2013). Higher Education in Saudi Arabia: Achievements, Challenges and Opportunities. New York: Springer.

Srimulyani, E. (2007). Muslim Women and Education in Indonesia: The Pondok Pesantren Experience. Asia Pacific Journal of Education 27(1):85-99. http://doi: 10.1080 /02188790601145564.

Supriadi, T., Julia, J., \& Firdaus, E. (2019). The Problems of Gender Equality: A Reconstruction of Islamic Doctrine. Journal of Social Studies Education Research, 10(2), 91-110. Retrieved from https://jsser.org/index.php/jsser/article/view/698

UN Women. (2012). Facts \& Figures. Retrieved from (https://www.unwomen.org /en/news/in-focus/commission-on-the-status-of-women-2012/facts-and-figures.).

UNESCO. (2014). Women and Girls' Education-Facts and Figures. Retrieved from (http://www.unesco.org/new/en/unesco/events/prizes-and-celebrations/celebrations /international-days/international-womens-day-2014/women-ed-facts-and-figure/).

Yasid, A. (2010). Pendidikan Tinggi di Pesantren: Studi Kasus Ma'had Ali Situbondo. Jurnal Penelitian Agama dan Keagamaan, 8(2), 3966-3999. http://dx.doi.org /10.32729/edukasi.v8i2.105 